Original Article

\title{
Drinking water quality of various sources in Peshawar, Mardan, Kohat and Swat districts of Khyber Pakhtunkhwa province, Pakistan
}

\author{
Qualidade de água potável de váris fontes dos distritos de Peshawar, Mardan, Kohat e \\ Swat da província de Khyber Pakhtunkhwa, Paquistão
}

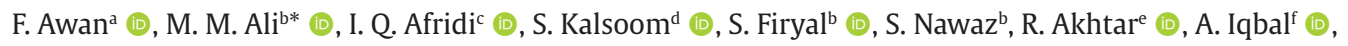

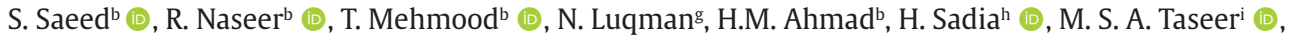

A. R. Khan ${ }^{\mathrm{b}}$ (i) and N. Rafique ${ }^{\mathrm{b}}$ (D)

aUniversity of Veterinary and Animal Sciences, Department of Epidemiology and Public Health, Lahore, Pakistan

bUniversity of Veterinary and Animal Sciences, Institute of Biochemistry and Biotechnology, Lahore, Pakistan

cLady Reading Hospital MTI, Urology Department, Peshawar, Pakistan

${ }^{d}$ Virtual University of Pakistan, Department of Biotechnology, Lahore, Pakistan

eUniversity of Veterinary and Animal Sciences, Department of Pathology, Lahore, Pakistan

fUniversity of Veterinary \& Animal Sciences, Department of Wildlife \& Ecology, Lahore, Pakistan

sDepartment of Livestock and Dairy Development, Punjab, Lahore, Pakistan

hBalochistan University of Information Technology, Engineering and Management Sciences, Department of Biotechnology, Quetta, Pakistan

iUniversity of Veterinary and Animal Sciences, Narowal Campus, Lahore, Pakistan

\begin{abstract}
The present study involves the chemical and bacteriological analysis of water from different sources i.e., bore, wells, bottle, and tap, from Peshawar, Mardan, Swat and Kohat districts of Khyber Pakhtunkhwa (KP) province, Pakistan. From each district, 50 water samples (10 samples from each source), regardless of urban and rural status, were collected from these sources and analysed for sulphates, nitrates, nitrites, chlorides, total soluble solids and coliforms (E. coli). Results indicated that majority of the water sources had unacceptable E. coli count i.e.> $34 \mathrm{CFU} / 100 \mathrm{~mL}$. E. coli positive samples were high in Mardan District, followed by Kohat, Swat and Peshawar district. Besides this, the some water sources were also chemically contaminated by different inorganic fertilizers (nitrates/nitrites of sodium, potassium) but under safe levels whereas agricultural and industrial wastes (chloride and sulphate compounds) were in unsafe range. Among all districts, the water quality was found comparatively more deteriorated in Kohat and Mardan districts than Peshawar and Swat districts. Such chemically and bacteriologically unfit water sources for drinking and can cause human health problems.
\end{abstract}

Keywords: faecal coliforms, sulphate, TSS, nitrite, chloride, nitrate, Peshawar, Kohat.

\begin{abstract}
Resumo
O presente estudo envolve a análise química e bacteriológica de água de diferentes fontes, ou seja, furo, poços, garrafa e torneira, dos distritos de Peshawar, Mardan, Swat e Kohat da província de Khyber Pakhtunkhwa (KP), Paquistão. De cada distrito, 50 amostras de água (10 amostras de cada fonte), independentemente do status urbano e rural, foram coletadas dessas fontes e analisadas para sulfatos, nitratos, nitritos, cloretos, sólidos solúveis totais e coliformes (E. coli). Os resultados indicaram que a maioria das fontes de água tinha uma contagem inaceitável de E. coli, ou seja, > 34 UFC / $100 \mathrm{~mL}$. As amostras positivas para E. coli foram elevadas no distrito de Mardan, seguido por Kohat, Swat e distrito de Peshawar. Além disso, algumas fontes de água também foram contaminadas quimicamente por diferentes fertilizantes inorgânicos (nitratos/nitritos de sódio, potássio), mas em níveis seguros, enquanto os resíduos agrícolas e industriais (compostos de cloreto e sulfato) estavam em níveis inseguros. Entre todos os distritos, a qualidade da água foi considerada comparativamente mais deteriorada nos distritos de Kohat e Mardan do que nos distritos de Peshawar e Swat. Essas fontes de água química e bacteriologicamente impróprias para beber podem causar problemas à saúde humana.
\end{abstract}

Palavras-chave: coliformes fecais, sulfato, TSS, nitrito, cloreto, nitrato, Peshawar, Kohat.

*e-mail: Muddassir.ali@uvas.edu.pk

Received: August 27, 2021 - Accepted: October 23, 2021

This is an Open Access article distributed under the terms of the Creative Commons Attribution License, which permits unrestricted use, distribution, and reproduction in any medium, provided the original work is properly cited. 


\section{Introduction}

Contaminated water is known as one of the major health risks in Pakistan (Ahmad et al., 2012a). Both chemical ions and microbial contamination are considered as the culprit. Common bacterial contaminants include E. coli, Salmonella, Shigella, and Campylobacter jejuni. On the other hand, viral contaminants like norovirus, rotavirus, enteroviruses, hepatitis causing viruses and parasitic agents e.g. Giardia, Cryptosporidium and Microsporidia etc. are mostly involved in water contamination (Leclerc et al., 2002). Among all these infectious contaminants, Coliform i.e. E. coli is considered as most prevalent infectious agent that is highly associated with the human and animal intestinal infections (Nkere et al., 2011).

In addition to microbial contamination, anions and cations in high quantity such as nitrates, nitrites, sulphates, and chlorides also cause serious threats to human and animal health. Nitrate and nitrite affect non-breastfed infants and cause 'blue baby syndrome' in them. In addition to this, it has no taste, colour and smell and can only be detected through chemical tests. According to World Health Organization (WHO) and Pakistan Research Council in Water Resources (PCRWR), nitrite and nitrate levels greater than 1-3 $\mathrm{mg} / \mathrm{L}$ and $10-50 \mathrm{mg} / \mathrm{L}$, respectively, can pose a risk to humans. It is gains entry through ingestion only drinking, cooking, teeth brushing (Rashid et al., 2018). On the other hand, chloride ions are potential cause of bad taste and hypertension because of its presence along with sodium ions. Addition to these studied ions, presence of sulphate ions in drinking water causes a laxative effect and dehydration. Its presence in drinking water also changes in the taste. For chlorides and sulphates, WHO and PCRWR have set standard limits to $250 \mathrm{mg} / \mathrm{L}$. In short, these ions, more than their standard limits, can cause major impact on human health (Feldman et al., 2007).

Pakistan is considered among those countries that have low sanitary conditions and lack of knowledge (Anwar et al., 2010). Among all the provinces, Khyber Pakhtunkhwa is considered as one of the most war stricken, flood affected, distant and highly impoverished area. It is reported that water-borne diseases are a huge menace for the population comprising only $47 \%$ of households with tap water and $61 \%$ with safe sanitations in Pakistan, several studies to monitor the drinking water quality have been carried out, but the remote, rugged and poverty stricken mountainous areas remained least monitored or almost neglected. After observing this situation, the present study has been conducted to investigate the bacteriological and chemical analysis of drinking water in most important districts i.e., Peshawar, Mardan, Kohat and Swat districts of Khyber Pakhtunkhwa (KP) Pakistan.

\section{Materials and Methods}

As mentioned earlier, Khyber Pakhtunkhwa is considered as one of the most war stricken area. Additionally, districts included in this study, such as Peshawar, Kohat, Swat and Mardan, were selected on the basis of high population, comparable less security risks, and considerable place for migrating war stricken populations.

\subsection{Sampling}

For both bacteriological and chemical analysis, water samples $(n=200)$ were collected in $50 \mathrm{~mL}$ sterile polyethylene bottles from 5 different sources i.e. bottles, wells, bore (115-380 feet), taps, and hand-pumps in a sterile manner (Ahmad et al., 2012b; Gwimbi, 2011). 50 samples were collected from each district. The purposive sampling was done to collect all the samples from each district. These samples were immediately stored at a temperature between 0 to $4{ }^{\circ} \mathrm{C}$ before processing (Anwar et al., 2010).

\subsection{Microbiological analysis}

For microbiological analyses, previously mentioned methods were followed after little modification (Akeju and Awojobi, 2015). Lauryl Triptose broth was used as a medium in presumptive coliform test (Ali et al., 2011; Anwar et al., 2010). Three sets of tubes were inoculated with $10 \mathrm{~mL}, 1 \mathrm{~mL}$ and $0.1 \mathrm{~mL}$ of each water sample. The tubes were incubated at $37{ }^{\circ} \mathrm{C}$ to $44{ }^{\circ} \mathrm{C}$ for $24-48$ hours and examined for acid and gas production. Following this presumptive coliform test, total coliform confirmatory test was performed using Brilliant Green Lactose Bile broth. For total coliform, these inoculated tubes were incubated at $37{ }^{\circ} \mathrm{C}$ for $24-48$ hours. For faecal coliform, these tubes were incubated at $44{ }^{\circ} \mathrm{C}$ and kept under observation for gas production. After faecal coliform confirmation, Eosin Methylene Blue (EMB) agar plates were used for detection of $E$. coli. These EMB plates were streaked by a loop dipped in the broth from each positive tube and checked for bacterial presence (Ali et al., 2011; Anwar et al., 2010).

\subsection{Chemical analysis}

Different chemical tests were performed to check the status of chemical ions i.e. Chlorides $(\mathrm{Cl})$, Nitrates $\left(\mathrm{NO}_{2}\right)$, Nitrates $\left(\mathrm{NO}_{3}\right)$, Sulphates $\left(\mathrm{SO}_{4}\right)$ and Total Soluble Solids (TSS) present in sampled water. These ions were analysed according to standard procedures (Feldman et al., 2007; Khan et al., 2012b; Soylak et al., 2002). For Nitrates $\left(\mathrm{NO}_{2}\right)$, Nitrates $\left(\mathrm{NO}_{3}\right)$, and Sulphates $\left(\mathrm{SO}_{4}\right)$ ions, Cadmium Reduction Method (Hach-8192) and SulfaVer4 (Hach-8051) by Spectrophotometer were utilized, respectively. For Chlorides $(\mathrm{Cl})$ determination, argentometric method using potassium chromate indicator and standard $\mathrm{AgNO}_{3}$ solution was utilized. For TSS determination, all the water samples were filtered through Beckman filter paper and dried in oven at $103-105^{\circ} \mathrm{C}$.

\subsection{Statistical analysis}

Basic descriptive statistical analysis was performed to interpret the maximum and minimum values in categories of ions and bacteria found in different districts and different sources by utilizing GraphPad Prism v6.0 for windows (GraphPad Software, Inc., San Diego, CA). AICcmodavg package of R- language was utilized in order to compare different groups using two way ANOVA test and Tukey HSD post -hoc test ( $\mathrm{p}$-value <0.05). 


\section{Results and Discussion}

\subsection{Microbiological analysis}

The results of bacteriological analysis for all districts are shown in Figure 1. This study analysed water from different sources present in each district and were found contaminated with bacteria, both total coliforms and E. coli (Table 1). The water samples from all the districts resulted in the varying trends of bacterial contamination. In Peshawar district, of 50 samples, 22 (44\%) samples were positive for total coliform and 14were positive for $E$. coli. The highest value of bacterial contamination was recorded in bore water/hand-pumps water 6 (60\%), tap water and hotel water followed by well water 4 (40\%) and bottle water $0 \%$. In Mardan district, among total 50 samples, 24 (48\%) and 22 (44\%) samples were positive for faecal coliform and $E$. coli respectively. The bacterial contamination was recorded as highest 8 (80\%) in well water and hotel water. In Kohat district, 34 (68\%) positive samples for faecal coliform and $22(44 \%)$ positive samples for $E$. coli were identified in 50 samples. The highest bacterial contamination was observed in tap water 8 (80\%) followed by hotel water 6 (60\%), bore water $6(60 \%)$, well water $4(40 \%)$ and bottle water 2 (20\%). In Swat district, 18 (36\%) faecal coliform positive samples and $14(28 \%)$ E. coli positive samples were identified. The bore water was revealed to be highly contaminated with 6 (60\%) contaminated samples whereas well water, tap water and hotel water were comparatively less contaminated i.e. 4 (40\%).

In present study, faecal coliform count $(>34 \mathrm{cfu} / 100 \mathrm{~mL}$ ) was far above the accepted WHO standard i.e., $0 \mathrm{cfu} / 100 \mathrm{~mL}$ in drinking water(WHO, 2004). These results indicate the presence of contact between human and animal wastes or possible mixing of drinking water with sewerage water. From bottle water, in all the districts, least bacterial counts were observed. These results were in fully agreement with the reports of Pakistan Research Council in Water Resources (PCRWR) (PCRWR, 2012). On the other hand, samples from hotels, taps and bore water were observed as highly contaminated that is similar to the previous studies (Ahad et al., 2000; Ali et al., 2011; Anwar et al., 2010). Pipelines are potential source of bacterial contamination as the distribution network of water supply comes in contact with waste-water and faeces (Moe and Rheingans, 2006; Younas et al., 2016; Rashid et al., 2021).

Table 1. Percentage of different water samples found contaminated with fecal coliforms and E. coli.

\begin{tabular}{|c|c|c|c|}
\hline Districts & Source & Faecal Coliform (\%) & E. coli (\%) \\
\hline \multirow[t]{5}{*}{ Peshawar } & Bore & 40 & 20 \\
\hline & Well & 20 & 20 \\
\hline & Bottled & 0 & 0 \\
\hline & Hotel & 0 & 60 \\
\hline & Tap & 20 & 40 \\
\hline \multirow[t]{5}{*}{ Mardan } & Bore & 0 & 40 \\
\hline & Well & 20 & 60 \\
\hline & Bottled & 0 & 0 \\
\hline & Hotel & 0 & 80 \\
\hline & Tap & 0 & 40 \\
\hline \multirow[t]{5}{*}{ Kohat } & Bore & 20 & 40 \\
\hline & Well & 20 & 20 \\
\hline & Bottled & 0 & 20 \\
\hline & Hotel & 0 & 60 \\
\hline & Tap & 0 & 80 \\
\hline \multirow[t]{5}{*}{ Swat } & Bore & 20 & 40 \\
\hline & Well & 20 & 20 \\
\hline & Bottled & 0 & 0 \\
\hline & Hotel & 0 & 40 \\
\hline & Tap & 0 & 40 \\
\hline
\end{tabular}

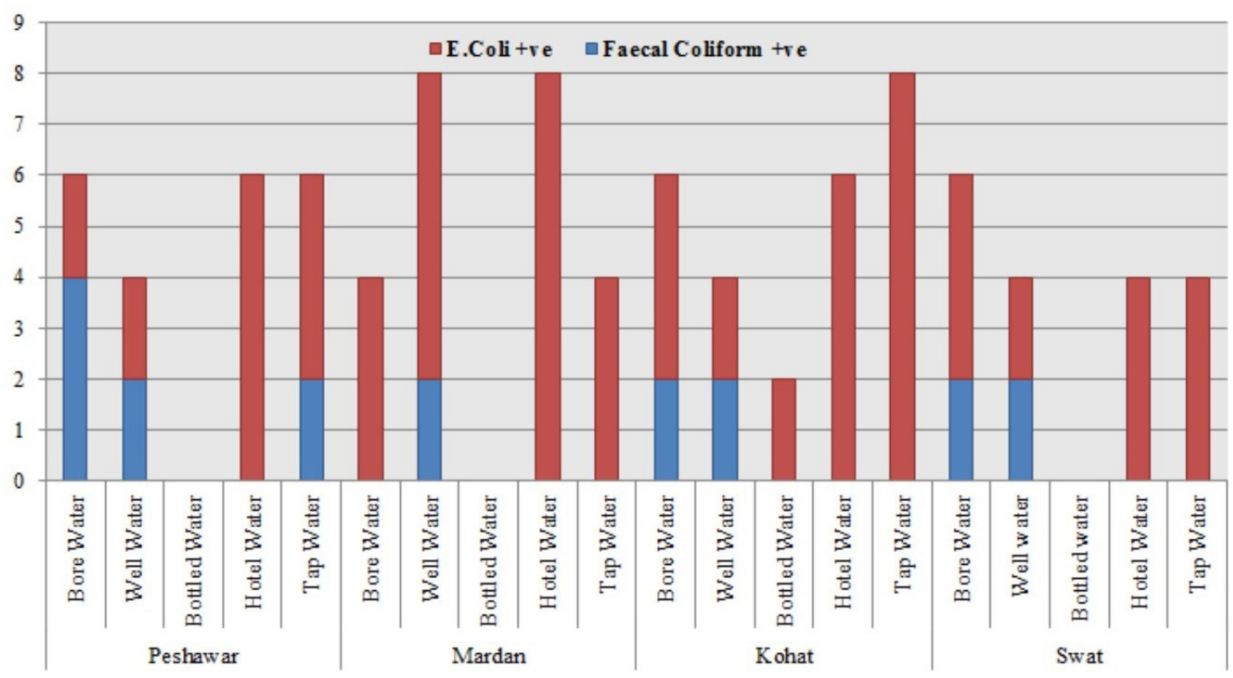

Figure 1. Microbiological quality of all the water samples collected from different sources across the four districts. The number of $E$. coli identified among the total number of coliforms identified. 


\subsection{Chemical analysis}

The highest concentration of sulphate was recorded in well water from district Peshawar with $233.2 \pm 62.88 \mathrm{mg} / \mathrm{L}$ (150-305 mg/L) ions whereas least concentration of $36.2 \pm 22.01 \mathrm{mg} / \mathrm{L}(8-65 \mathrm{mg} / \mathrm{L})$ ions was recorded in Bore water of district Mardan (Figure 2). The sulphate content of all water samples from these districts was permissible to drink according to PSQCA and WHO standards i.e., $250 \mathrm{mg} / \mathrm{L}$ (Figure 2a). When comparing with other water sources across the districts, higher concentrations were observed in well water and hotel water whereas bore water had least sulphate contents. For water of the Khyber Pakhtunkhwa, the high values of sulphates were reported from hotel water and well water sources(Hussain et al., 2012; Khan et al., 2005). In all the cases, water of Khyber
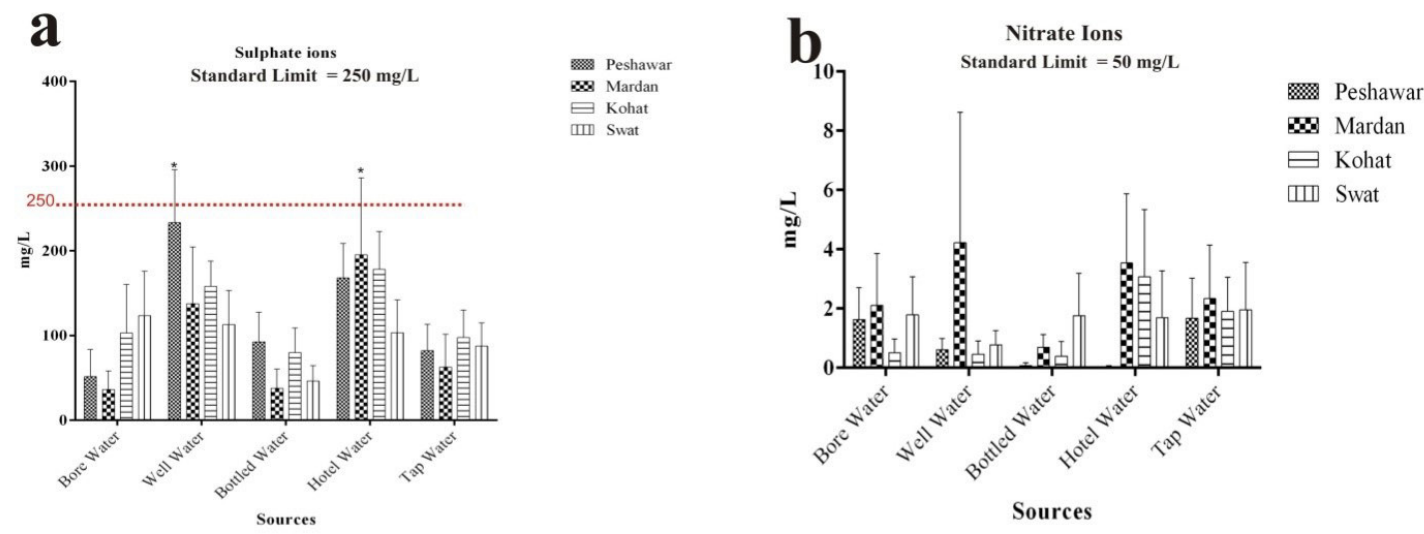

Sources
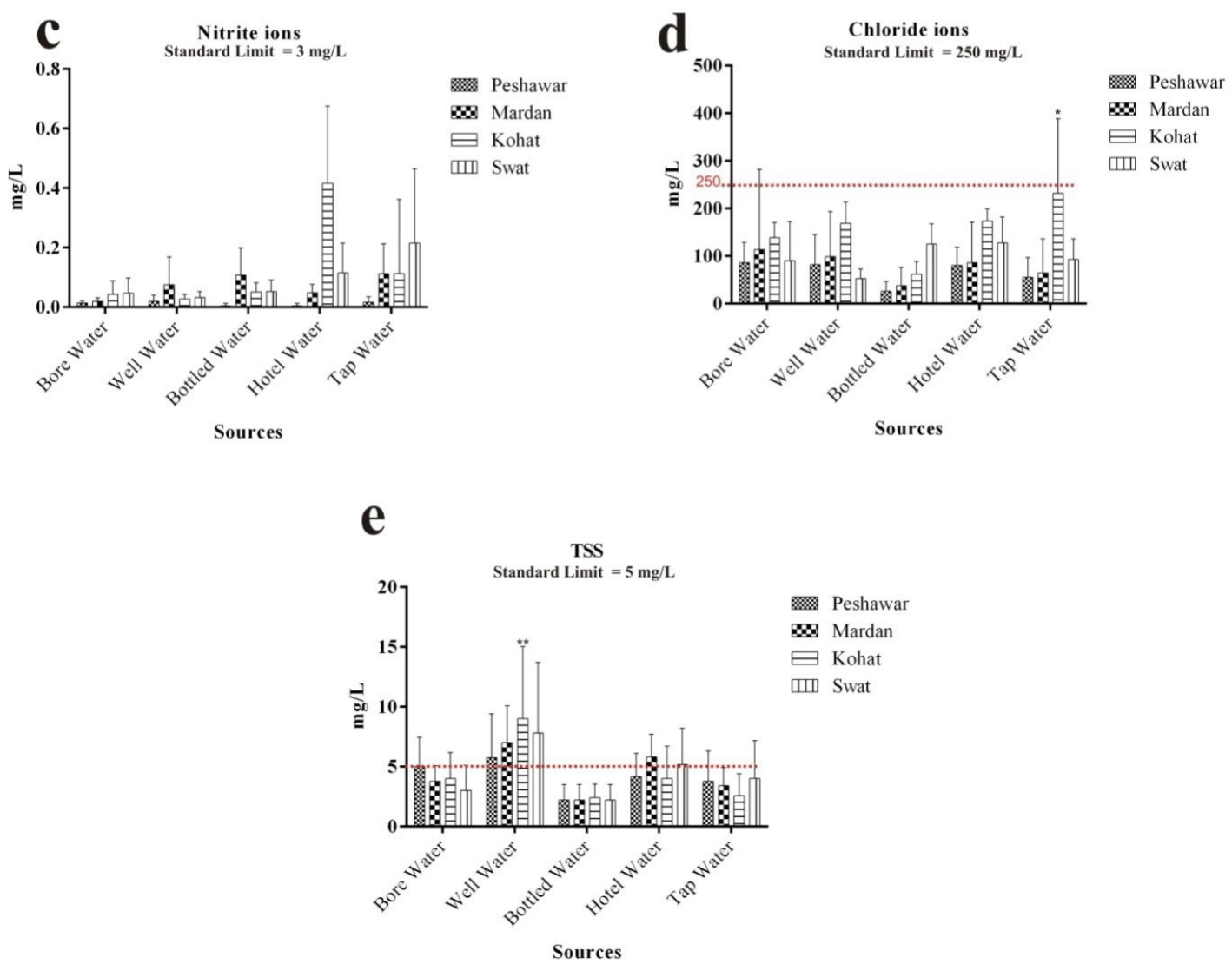

Figure 2. Chemical analysis of water quality collected from different sources across the four districts. 
Pakhtunkhwa is not polluted according to their Sulphates content i.e. $250 \mathrm{mg} / \mathrm{L}$ is permitted (Alam et al., 2008). The source of sulphates in water can be from both natural and human sources. It can also contaminate the water when high rainfall or industrial waste water comes in contact (Azizullah et al., 2011). Water containing magnesium sulphate at levels above $600 \mathrm{mg} / \mathrm{L}$ acts as a purgative in humans. The presence of sulphate in drinking water can also result in a noticeable taste and hardness (Azizullah et al., 2011; Heydari and Bidgoli, 2012).

The highest value of nitrate i.e., $4.22 \pm 4.41 \mathrm{mg} / \mathrm{L}$ (0.336-11.65 mg/L) was observed in well water of Mardan District whereas lowest observed value $0.024 \pm 0.002 \mathrm{mg} / \mathrm{L}$ (0-0.12 $\mathrm{mg} / \mathrm{L})$ belonged to hotel water from Peshawar district (Figure $2 \mathrm{~b}$ ). All the values of nitrate ion in sampled sources were present in permissible ranges of PSQCA and WHO standards i.e. $\leq 20 \mathrm{mg} / \mathrm{L}$ or below excessive limit of $50 \mathrm{mg} / \mathrm{L}$ (Alam et al., 2008; WHO, 2004). The trend of nitrate ions was consistently low in bottle water, hotel water and tap water in all the districts. These results are in accordance with the previous reported studies in all the districts (Alam et al., 2008; Azizullah et al., 2011; Hussain et al., 2012). The potential source must be the un-treated water wastes from factories.

Nitrite ions were recorded as higher concentration in hotel water in Kohat i.e. $0.416 \pm 0.26 \mathrm{mg} / \mathrm{L}(0.07-0.67 \mathrm{mg} / \mathrm{L})$. On the other hand, bottle water from Peshawar district with value of $0.0044 \pm 0.0093 \mathrm{mg} / \mathrm{L}(0-0.21 \mathrm{mg} / \mathrm{L})$ was considered as lowest nitrite concentration among all the sources (Figure 2c). For nitrite ions, all these sources were revealed to be perfectly fit for human consumption according to defined PSQCA ( $1 \mathrm{mg} / \mathrm{L})$ and WHO standards ( $3 \mathrm{mg} / \mathrm{L}$ ).Hotel water and tap water were found with higher nitrite-nitrogen levels but within the permissible limits of $1 \mathrm{mg} / \mathrm{L}(\mathrm{WHO}, 2004)$. These results are in accordance with the previous studies (Azizullah et al., 2011; Khan et al., 2000, 2013). This higher level infers that these water sources may be used for bathing, hand washing, and dishwashing. Elevated nitrite levels in well water may indicate different problems related to water quality that can cause several health issues i.e., blue babies syndrome.

Chloride ions with value of $231.8 \pm 156.7 \mathrm{mg} / \mathrm{L}$ $(59-450 \mathrm{mg} / \mathrm{L})$ was ranked as highest in the tap water of Kohat district. The lowest value of $26.6 \pm 20.25 \mathrm{mg} / \mathrm{L}$ (8-59 mg/L) was present in bottle water of Peshawar district (Figure 2d). The chloride ion content, in all the districts and sources, was in acceptable range i.e. $250 \mathrm{mg} / \mathrm{L}$ except Tap water from Kohat district.

According to WHO and Pakistan Standards and Quality Control Authority, the permissible limit for chlorides is $250 \mathrm{mg} / \mathrm{L}$ (Moe and Rheingans, 2006; Soylak et al., 2002). This water is thus acceptable for chlorides and of good quality with respect to chlorides. These results are in accordance with all the previous conducted studies in all these districts except Kohat (Ahmad et al., 2012a; Alam et al., 2008; Ali et al., 2011; Azizullah et al., 2011; Khan et al., 2013). In Kohat district, samples from well water and tap water had unacceptable chloride levels that have been also reported in earlier studies (Khan et al., 2012b, 2013). The excessive intake of drinking-water containing sodium chloride at concentrations above $250 \mathrm{mg} / \mathrm{litre}$ has been reported to produce hypertension(WHO, 2004). Possible source may be due to leaching of soil minerals, increasing salinity, washing of utensils containing pesticides and nearby restaurants (Rashid et al., 2018).

TSS level was significantly high i.e. $9 \pm 2.70 \mathrm{mg} / \mathrm{L}$ in well water of Kohat district and the least value i.e. 2.2 $\pm 0.58 \mathrm{mg} / \mathrm{L}$ was recorded in bottled water of Peshawar district. The trend of TSS level was higher $(>7 \mathrm{mg} / \mathrm{L})$ in well water of all districts followed by hotel water (5-7 mg/L). Bore water, bottle water and tap water were present in acceptable TSS level limits $(<5 \mathrm{mg} / \mathrm{L}$ ) (Figure $2 \mathrm{e}$ ). On the other hand, allowable standard values of Total Soluble Solid (TSS) range below $5 \mathrm{mg} / \mathrm{L}$ (WHO, 2004). Well water sources across the districts were found with high TSS level $(5.75-9 \mathrm{mg} / \mathrm{L})$ indicating that well water is being exposed to certain contaminated sources. These results are in accordance with Khan et al. (2012a).

Among the districts, Well water from Kohat had the highest value which is completely in agreement with previous study (Azizullah et al., 2011; Khan et al., 2013). TSS content of water causes salinity or cloudy appearance and mainly occurs due to carbonates and bi-carbonates. These suspended soluble compounds are possibly released from the sedimentary rocks, industrial wastes and sewerage pipelines (Azizullah et al., 2011).Among the sources, hotel and wells near to sewage areas, canals, common drinking places of animals, and factory areaswere found more contaminated as compare to others.

\section{Conclusion}

This study concludes that water of KPK province is not chemically and microbiologically fit for drinking especially from unprotected sources that possess microbial contamination i.e., wells and hotels. When drinking water, people must ensure the purity of water otherwise results could be drastic. The microbial contamination can be prevented by taking certain precautionary measures. For family and children in home, Filtered and Boiled water should be used as there is risk of contamination of tap water. When in journey, bottle water is a good option. We recommend that water surveys must be continued to detect baseline data and different levels of other ions and heavy metals. This will be helpful in determining the future needs and tailoring of future policies.

\section{References}

AHAD, K., ANWAR, T., AHMAD, I., MOHAMMAD, A., TAHIR, S. and AZIZ, S., 2000. Determination of insecticide residues in groundwater of Mardan Division, NWFP, Pakistan: a case study. Water S.A., vol. 26, pp. 409-412.

AHMAD, I., BAHADAR, K., ULLAH, H., REHMAN, A., IQBAL, H., WAHAB, A., HAQ A.U., KHAN, M.A. and IJAZ, F., 2012a. Physicochemical analysis of drinking water sources at sampling point of Billitang, KDA, Nasrat Khel and Chongee of District Kohat, K.P.K., Pakistan. International Journal of Science Innovations and Discoveries, vol. 2, pp. 598-609.

AHMAD, S.R., KHAN, M.S., KHAN, A.Q., GHAZI, S. and ALI, S., 2012 b. Sewage water intrusion in the groundwater of Lahore, its causes 
and protections. Pakistan Journal of Nutrition, vol. 11, no. 5, pp. 484-488. http://dx.doi.org/10.3923/pjn.2012.484.488.

AKEJU, T. and AWOJOBI, K.O., 2015. Enumeration of coliform bacteria and characterization of Escherichia coli isolated from Staff Club swimming pool in Ile-Ife, Nigeria. Microbiological Research, vol. 6, pp. 5972.

ALAM, S., AHMAD, S. and BANGASH, F.K., 2008. Drinking water quality of Swat district. Journal of the Chemical Society of Pakistan, vol. 30, pp. 2008.

ALI, J., HUSSAIN, A. and ABID, H., 2011. The occurrence of coliforms bacteria in water reservoir at different schools of district Peshawar. Pakistan Journal of Biochemistry and Molecular Biology, vol. 44, pp. 64-67.

ANWAR, M.S., LATEEF, S. and SIDDIQI, G.M., 2010. Bacteriological quality of drinking water in Lahore. Biomedica, vol. 26, pp. 66-69.

AZIZULLAH, A., KHATTAK, M.N.K., RICHTER, P. and HÄDER, D.-P., 2011. Water pollution in Pakistan and its impact on public health: a review. Environment International, vol. 37, no. 2, pp. 479-497. http://dx.doi.org/10.1016/j.envint.2010.10.007. PMid:21087795.

FELDMAN, P.R., ROSENBOOM, J.-W., SARAY, M., SAMNANG, C., NAVUTH, P. and IDDINGS, S., 2007. Assessment of the chemical quality of drinking water in Cambodia. Journal of Water and Health, vol. 5, no. 1, pp. 101-116. http://dx.doi.org/10.2166/ wh.2006.048. PMid:17402283.

GWIMBI, P., 2011. The microbial quality of drinking water in Manonyane community: maseru District (Lesotho). African Health Sciences, vol. 11, no. 3, pp. 474-480. PMid:22275942.

HEYDARI, M. and BIDGOLI, H., 2012. Chemical analysis of drinking water of Kashan District, Central Iran. World Applied Sciences Journal, vol. 16, pp. 799-805.

HUSSAIN, J., SHAH, J., HUSSAIN, W., ALI, R., SOUSA, L.J., LOPES, W.A., KHAN, I. and NASCIMENTO, I.A., 2012. Evaluation of the Quality of Drinking Water of Mardan District, KPK, Pakistan. American-Eurasian J. Agric. \& Environ. Sci, vol. 12, pp. 1047-1051.

$<$ jrn>KHAN, A., MUMTAZ, MIN, K.-S., MARWAT, G. and RIAZ, M., 2005. Potable water quality characteristics of the urban areas of Peshawar (Pakistan) part 2: well water. Journal of the Chemical Society of Pakistan, vol. 27, pp. 239-245.</jrn>.

KHAN, A.R., HAQ I.U., KHAN, W.A., AKIF, M., KHAN, M. and RIAZ, M., 2000. Quality characteristics of potable water of Mardan City (Pakistan) and surrounding areas. Journal of the Chemical Society of Pakistan, vol. 22, pp. 87-93.

KHAN, N., HUSSAIN, S.T., HUSSAIN, J., JAMILA, N., AHMED, S., ULLAH, R., ULLAH, Z., ALI, S. and SABOOR, A., 2012a. Chemical and microbial investigation of drinking water sources from Kohat, Pakistan. International Journal of Physical Sciences, vol. 7, pp. 4093-5002.
KHAN, N., HUSSAIN, S.T., SABOOR, A., JAMILA, N., AHMED, S., ULLAH, R., ULLAH, Z., ALI, S., LEE, S.-I. and KIM, K.S., 2012b. Bacteriological investigation of ground water sources in selected urban areas of district Mardan, Khyber Pakhtunkhwa, Pakistan. African Journal of Biotechnology, vol. 11, pp. 11236-11241.

KHAN, N., HUSSAIN, S.T., KHAN, A. and KIM, K.S., 2013. Physiochemical investigation of drinking water sources from Tehsil Lachi, Kohat. American Journal of Research Communication, vol. 1, pp. 170-190.

LECLERC, H., SCHWARTZBROD, L. and DEI-CAS, E., 2002. Microbial agents associated with waterborne diseases. Critical Reviews in Microbiology, vol. 28, no. 4, pp. 371-409. http://dx.doi. org/10.1080/1040-840291046768. PMid:12546197.

MOE, C. and RHEINGANS, R., 2006. Global challenges in water, sanitation and health. Journal of Water and Health, vol. 4, suppl. 1, pp. 41-57. http://dx.doi.org/10.2166/wh.2006.0043. PMid:16493899.

NKERE, C., IBE, N. and IROEGBU, C., 2011. Bacteriological quality of foods and water sold by vendors and in restaurants in Nsukka, Enugu State, Nigeria: a comparative study of three microbiological methods. Journal of Health, Population, and Nutrition, vol. 29, no. 6, pp. 560-566. PMid:22283029.

PAKISTAN RESEARCH COUNCIL IN WATER RESOURCES - PCRWR, 2012. National Research Agenda on Water 2016-25. Islamabad: PCRWR.

RASHID, H., MANZOOR, M.M. and MUKHTAR, S., 2018. Urbanization and its effects on water resources: an exploratory analysis. Asian Journal of Water, Environment and Pollution, vol. 15, no. 1, pp. 67-74. http://dx.doi.org/10.3233/AJW-180007.

RASHID, M., KHAN, M.N. and JALBANI, N., 2021. Detection of human adenovirus, Rotavirus, and Enterovirus in tap water and their association with the overall quality of water in Karachi, Pakistan. Food and Environmental Virology, vol. 13, no. 1, pp. 44-52. http:// dx.doi.org/10.1007/s12560-020-09448-8. PMid:33180282.

SOYLAK, M., AYDIN, F., SARACOGLU, S., ELCI, L. and DOGAN, M., 2002. Chemical analysis of drinking water samples from Yozgat, Turkey. Polish Journal of Environmental Studies, vol. 11, pp. 151-156.

WORLD HEALTH ORGANIZATION - WHO, 2004. Guidelines for drinking water quality. Geneva: WHO, vol. 2, $231 \mathrm{p}$.

YOUNAS, M., SIDDIQUI, F., NOREEN, Z., BOKHARI, S.S., GOMEZDUARTE, O.G., WREN, B.W. and BOKHARI, H., 2016. Characterization of enteropathogenic Escherichia coli of clinical origin from the pediatric population in Pakistan. Transactions of the Royal Society of Tropical Medicine and Hygiene, vol. 110, no. 7, pp. 414-420. http://dx.doi.org/10.1093/trstmh/trw047. PMid:27496516. 